\title{
Evaluation of the diversification of rural landscape in Slovakia after 1989 with a focus on the built-up area of municipalities: a case study of Podhájska municipality
}

\author{
Michaela ŽONCOVÁ ${ }^{1}$
}

\begin{abstract}
The rural landscape in Slovakia was a synonym of agricultural production until 1989 and countryside has fulfilled specifically a productive function. Agriculture still plays a very important role in the Slovak countryside, but after 1989 there have been socio-economic changes in Slovak economy, which has reoriented to the market economy, resulting in changes of the ownership of enterprises, production processes and competition in the market. Countryside has been looking for new poles of development, what can be termed as the diversification of the functions of the countryside, i.e. the transformation of a mono-functional space into a multifunctional space. However, the increase in the amount of rural functions also results in changes of the land cover structure, which are most evident in built-up areas of municipalities. The aim of the paper is to evaluate the changes of the land cover structure of the rural landscape in Slovakia, focusing on the built-up area of the monitored municipality. The municipality of Podhájska, which is the centre of the Termál micro-region, was selected as the model territory and was researched as a case study. In this region, there is a constantly developing tourism, services and business instead of focusing only on agriculture. Changes in the land cover structure were monitored using aerial images from 1987 and 2014 (updated by field research) and the extent and nature of these changes were then analysed by Analysis tools in ArcGIS 10.2. The changes occurred in almost a quarter of the monitored area. Particularly, the use of gardens around houses has changed and they transformed from production to recreation area. The built-up area is also thickened and expanded under the influence of an increase of the tourism importance, especially in the area of former vineyards that had a long tradition in the municipality. The results of the research point to the loss of rural identity in case of increasing amount of function. Similar case studies should serve as base material for documents dealing with the sustainable development of rural areas.
\end{abstract}

Keywords: rural landscape, GIS, diversification, land cover structure, landscape changes

\section{Development of countryside in Slovakia - an introduction}

The rural space in Slovakia was influenced by several development periods before 1989, which shaped its function and visual aspect. Agriculture in the countryside advanced at the turn of the $19^{\text {th }}$ and $20^{\text {th }}$ century due to foundation of first agricultural cooperatives. After World War II the countryside was a synonym of agricultural production that provided food for the population. Since the 1950s the agricultural landscape has undergone radical changes. Löw, J. and MíchaL, I. (2003) mention the term of "communism in the landscape" and they see the main negatives in the central management. This period was characterized by a strong use of chemicals, mechanization and intensification in agriculture. United agricultural cooperatives have arisen, the mosaic of the landscape has been changed and the land was unified. In the 1960s, under the influence of industrialization, the young rural population has

\footnotetext{
${ }^{1}$ Department of Geography and Geology, University of Matej Bel, Tajovského 40, Banská Bystrica, Slovakia. E-mail: michaela.zoncova@umb.sk
} 
been moving out to towns and cities for a better quality of life. The rural population was, thus, very old (Burian, J. et al. 2013). In the 1970s and 1980s, the main well-developed catchment municipalities were formed, where all the activities and services were concentrated. The surrounding municipalities were on the downgrade.

After the collapse of communism, in 1989, the economy transformed from a centrally planned economy into a market economy (transition economy) in Central Europe. These countries have opted for a market mechanism, with the main elements of privatization, enterprise restructuring, market liberalization (RoLAND, G. 2000). The return of land and the increase of land trade have allowed the return of private farmers. Social development has resulted in the extinction of many agricultural cooperatives and businesses in rural areas and their insufficient use and dilapidation of agricultural buildings has been linked to the formation of brownfields. One of the most important elements of the transformation in the countryside was the restitution of land to the original owners. This change has not had a very powerful landscape manifestation, because the expected effect of the increase in private farming on land was not met due to the loss of bond of man to the soil, lack of domestic capital, aggravated conditions for agricultural business and especially legislative and administrative barriers (IzAKovičová, Z. 2012). Because of these barriers land owners can in many cases just rent their land to large-scale farmers or the land owners are still unknown.

Rural settlements are looking for resources for further development and want to gain the most of their potential. Their aim is, on the one hand, to maintain agricultural production and on the other hand to enable diversification into other activities, e.g. rural development towards a recreation and tourism and improvement of the lives of rural inhabitants (PĚLuCHA, M. et al. 2009). Negative is the loss of agricultural land as a result of the construction of new buildings (family houses, recreational complexes, manufactur- ing enterprises), which often do not respect the environmental and visual aspects of the countryside. Unharmed remains of rural decline are also agricultural, state, residential or industrial and other brownfields. Of the positive phenomena of the transitive economy, it is worth mentioning environmental measures aimed at eliminating sources of environmental pollution.

In the last decade, there has been a focus on drawing the funds for revitalizing dilapidated and unused land and brownfields in the countryside. Revitalization (revival, return of life) means the correction of an anthropogenically affected landscape or its part into a state connected with nature, a state approaching the original state.

\section{Multifunctional countryside}

At present, new terms associated with land use, as well as land use in the countryside multifunctional land use (NÉmethová, J. 2010), integrated land use (SPIŠIAK, P. 2005) are being used. In the document The Future and Rural Society (1988), a "new rural model" was presented and demonstrated. The countryside is not only perceived as a place for agricultural production, but it also becomes a place for small and mediumsized enterprises of a non-agricultural nature. Also, the countryside becomes a place for recreation and also becomes a basis for the ecological stability of the environment. The production function is receding and is replaced by consumption (land purchase, home, tourism associated with the consumption of traditional meals and drinks in local restaurants, visits of organized events, etc.) (HrušKa, V. 2013).

The concept of multi-functionality has been gradually applied not only to agriculture but also to the countryside as a whole. Holmes, J. (2006, 2012) regards the multifunctional transition as a transition from production to consumer and conservation functions. There is also a new strong political force in the countryside-environmentalism. 
Multi-functionality and environmentalism included in concept of "green infrastructure" are becoming highly relevant for rural areas and landscapes. A significant impact on the development of the countryside and its renewal was the entry of Slovakia into the European Union in 2004.

\section{Rural landscape as an object of research}

Woods, M. (2011) argues that from the perspective of geography is viewed mainly the agriculture, the impact of human activity on rural areas, rural studies and land use. The benefit of this view on the countryside lies mainly in placing emphasis on spatial differentiation and exploration of the landscape and its interaction with the human factor. The impact of the human factor as the main actor of agricultural activity in the countryside is the subject of many studies, but the emphasis is put largely on the non-built-up area where this agricultural activity predominantly takes place. In scientific papers dealing with the rural landscape in Slovakia, we can find studies focusing mainly on the change of the land cover structure (KANIANSKA, R. et al. 2014), the impact of tourism on the landscape (KLAUčo, M. et al. 2017), diversification of the rural landscape (Málikové, L. and KlobuČNír, M. 2017), function of agriculture in countryside (BAZIK, J. and MuchovÁ, Z. 2016; ŠPUlerovÁ, J. et al. 2017), rural population (Simpach, O. and Pechrová, M. 2016), green infrastructure and sustainable countryside (ТóTH, A. et al. 2016), the potential of the rural landscape (ŠTĚPÁNKOVÁ, R. and BiHuŇové, M. 2012) or multi-functionality of the countryside (BezÁk, P. and МттснLEY, J. 2014; BoHÁtová, Z. et al. 2015).

The change of rural functionality is evident mainly in built-up areas of municipalities, where new buildings, a change in the image of the countryside, revitalization, concentration of services connected with new functions are noticeable (Novákové, G. and

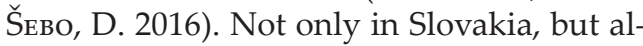
most in every European country is tourism one of the most significant driving forces in countryside. People want to spend time "close to nature" or they just want to "enjoy the countryside" (KulCSÁR, N. 2015). These all research point out to gradually increasing multi-functionality of countryside.

The main research question is how the multi-functionality of countryside caused by socio-economic changes after 1989 in Slovakia has influenced land cover structure of built-up area of countryside. The aim of this paper is research the changes in the land cover structure in the built-up area under the influence of functional changes in the countryside after 1989, pointing to the fact that the mono-functional countryside is becoming a multifunctional countryside and how the landscape diversifies and how new functions enter into it. For this research we need to make comparison of land cover structure between two periods - before 1989 and current state. Therefore, the goal is to create maps of land cover structure using aerial images and then to assess the most significant changes in landscape.

\section{Study area}

The municipality of Podhájska is located in western Slovakia, in the Nitra self-governing region, in the district of Nové Zámky (Figure 1). The total area of the municipality in 2017 was 11,116.3 ha and the number of inhabitants reached 1019 (31.12.2017). Podhájs$\mathrm{ka}$ is a centre of Termal microregion, which consists of 13 municipalities: Bardoňovo, Čechy, Dedinka, Dolný Ohaj, Hul, Kolta, Maňa, Podhájska, Pozba, Radava, Trávnica, Vel'ké Lovce and Vlkas. Podhájska was founded in 1960 by the unification of two municipalities - Belek and Svätuša, whose history dates back to the $11^{\text {th }}$ and $12^{\text {th }}$ centuries.

This municipality was selected as the model territory and case study on the basis of the results of the multi-criteria analysis in which it ranked first and reached the highest level of diversification among the 13 municipalities of the micro-region (Žoncové, M. 2017) 


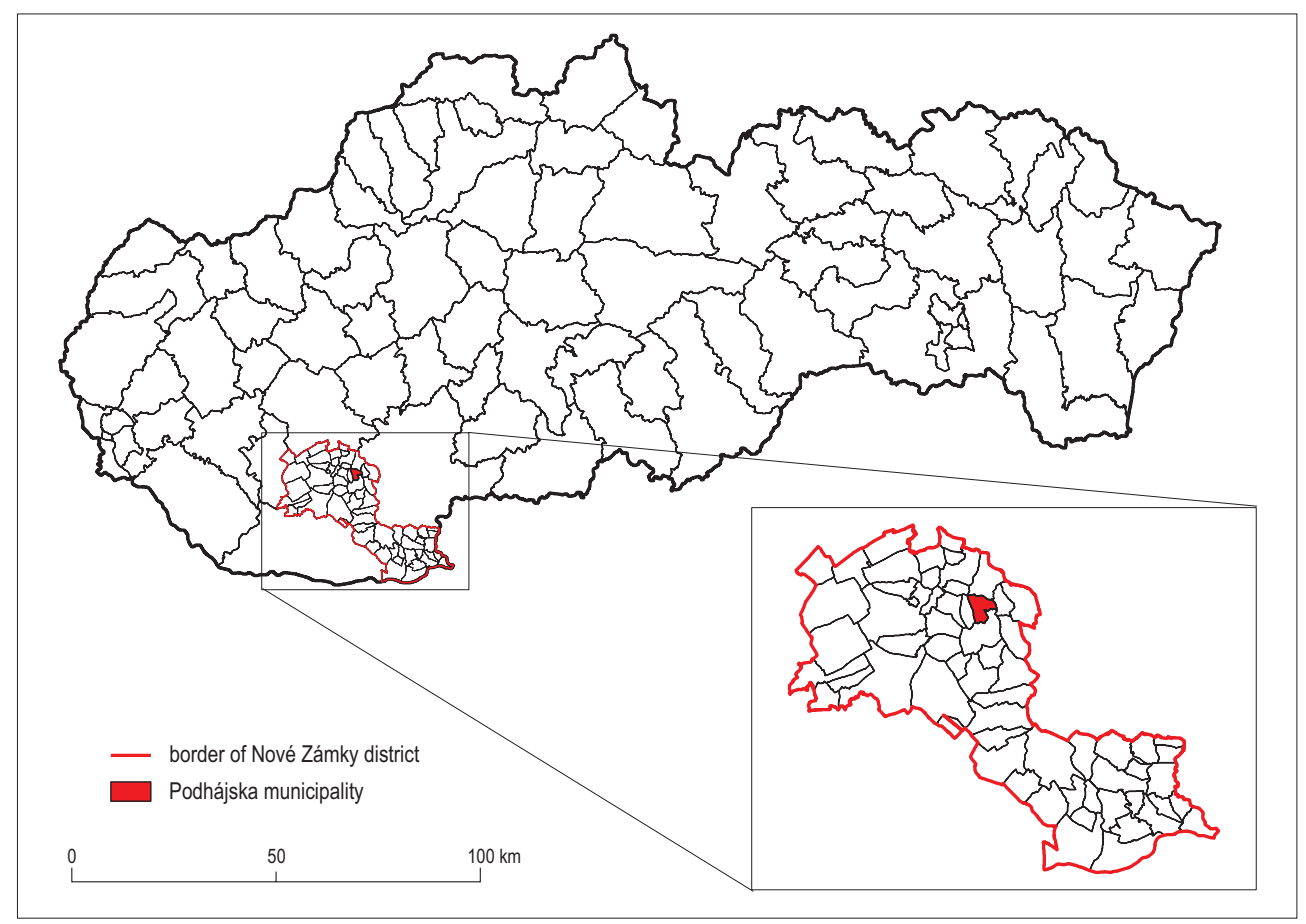

Fig. 1. Localisation of interested area of Podhájska municipality in Slovakia. Source: Žoncová, M. by ArcGIS 10.1

and also because of the increasing importance of another function (non-agricultural). Nowadays, the landscape in this area is partly formed by the development of tourism, which is developing thanks to the evergrowing popularity of the thermal aquapark in Podhájska. Podhájska is well-known for the thermal aquapark and thanks to it, the TREND journal ranked this aquapark on the $5^{\text {th }}$ position in the most visited places in Slovakia in 2005 (TREND, 2006) and on the $52^{\text {th }}$ position in the ranking of the most profitable companies in Slovakia in period 20122016 (Haluza, I. 2017). The municipality of Podhájska has a hilly relief, which is largely used for agricultural activity. The territory is rich in mineral and thermal waters with the most important locality in Podhájska, where water is used for treatment of the locomotive system, the respiratory system and skin eczema. Tourism has begun to build its prominent position in 1973 when workers of Nafta Gbely Company began drilling under the vineyards behind the Liska stream and after reaching a depth of 1,900 meters, $90^{\circ} \mathrm{C}$ of hot water was fired. The citizens built here in 20 days two swimming pools, which are in function until today. This rural municipality has looked for new poles of development after 1989 because of decline of agriculture and increase of unemployment.

\section{Data}

Land cover structure can be interpreted in orthophoto images in different ways. In European countries, the most widespread interpretation is currently based on CORINE Land Cover methodology (Feranec, J. and OřAhel, J. 2001) or Urban Atlas data (PAzúr, R. et al. 2017). We were able to ob- 
serve changes in the landscape structure using aerial images in software ArcGIS 10.1 by creating maps of land cover structure from two observed years:

- 1987 - for creating map of land cover structure, we used panchromatic (black and white) aerial photos provided by Topography Institute of Colonel Jan Lipsky in Banská Bystrica (TICJL) with resolution $58 \mathrm{~cm} / 1 \mathrm{px}$.

- 2016 - for creating map of current land cover structure, we used the newest aerial photos (from 2014) provided by web portal "mapy.cz" with resolution $25 \mathrm{~cm} / 1 \mathrm{px}$. We also checked and updated land cover structure on these photos with field research, which took place in 2016. Although the latest available satellite imagery is available on Google Maps, these images do not match the quality level needed to get close to the built-up areas of the municipalities.

\section{Methods}

Creating maps of land cover structure in 1987 and 2016

For comparing and analysis of changes in built-up area of Podhájska, we made maps of land cover structure in 1987 and 2016 using the aerial images. The next step in processing aerial images is their geo-referencing, digitization and subsequent vectoring of landscape elements in ArcGIS 10.1 over the reference periods. The mapping of the landscape structure in the built-up area of Podhájska was implemented in detail into the level of landscape elements, which are grouped into eight groups of landscape elements (FERANEC, J. et al. 1996; RužıčKa, M. 2000; Vojteková, J. 2013):

- Elements of forest vegetation (monitored landscape elements: groves);

- Elements of grasslands and pastures (occurrence in the observed area was not recorded);

- Elements of agricultural lands (monitored landscape elements: fields; vineyards);
- Elements of rocks and raw soils (occurrence in the observed area was not recorded);

- Elements of water courses and water bodies (rivers, streams);

- Elements of settlement and recreational areas (individual housing area; collective housing area; gardens of houses (production); gardens of houses (recreational); churches, chapels, bell towers; cemeteries; statues, crosses, sculptures; sport fields; swimming pools and aquaparks; playgrounds; buildings of public administration; preschool and school facilities; retail trade facilities; medical facilities; restaurants; cafes and pubs; cinema; paved sidewalks; parks, residential grasslands woods and scrubs; hotels, guesthouses; private accommodation; apartment houses; campsites; other unused areas);

- Elements of technical structures (industrial areas; farms, agricultural yards);

- Elements of transportation (main roads; other roads; railway line; parking; bus stop and station; gas station; railway station).

When mapping accommodation facilities, we combined a number of information sources available information from the internet (www.ubytovanienaslovensku.sk), from the municipal websites as well as from field research. Subsequently, we have categorized accommodation facilities according to their equipment (hotel, pension, apartment house, private accommodation, etc.). We also distinguish two types of gardens - recreational and production gardens. The main difference was visible on aerial images, where in recreational gardens were visible pools, lawn, parking places, gazeboes, etc. and their function consists in aesthetic, relax and fun. On the other hand, in the production garden was considerably visible a segmentation into small zones, where people grown their own vegetable and fruit. Based on the predominance of one function, the garden was included in the one of these categories.

From aerial images, only size, localization, but not the function of the building, can be seen. OŤahel, J. and Feranec, J. (1997) high- 
light the importance of field research in determining the function of objects and detailed mapping of the territory over a longer period of time with a maximum of information. Since the function of an object is not readily recognizable from an aerial image, it is important field research to determine the functionality of each object and its localization. When creating a map of the secondary landscape structure in 1987, we consulted the function of the buildings in this period with the mayor, the employees of the information office, but also with the inhabitants of the municipality. We also studied archive records where we found out, for example, when the building of a shop, a cooperative, a general office, schools were built. We also reached statistical database of accommodation facilities from Statistical Office of Slovak republic and municipal databases.

\section{Analysis of changes in land cover structure}

To analyse changes in the landscape in ArcGis 10.1, several methods have been developed that are engaged in detail by Singh (1989). In our research, we have used the Intersect tool in ArcToolbox (Analysis Tools $\rightarrow$ Overlay $\rightarrow$ Intersect) to create intersections of existing layers (in our case, the two monitored years) and a new layer is created with an attribute table with data from both layers. The "Intersect" tool for analysing changes in the landscape structure was also used by Mackenzie, J. (2009), Benini, L. et al. (2010),
Chirici, G. et al. (2006) and Coughlan, M.R. (2014). In the newly created layer which is created with the Intersect function, we can then select polygons in the attribute table that have the same code of landscape element group in both observed years.

Subsequently, the selected polygons are exported to the new layer that characterizes the areas in which the changes occurred in the two observed years from one landscape elements to another. In this way are identified areas in the landscape that were subject to change. Because we have linked two attribute tables using Intersect function, we can also identify the nature (character) of the change, i.e. to determine changes from one landscape elements to another landscape element. To analyse the nature of the changes, we calculated the extent of all existing polygons (areas). Subsequently, we calculated the percentage of landscape elements in year $x$ changed to landscape elements in year $y$ from the total area of the changed landscape structure in the observed area in the time horizon of years $x-y$. Based on the results, it is possible to create scenarios for the future development of the landscape of the monitored area.

\section{Results}

On the basis of the map comparison, we found out that the changes were observed on an area of $367,145.7 \mathrm{~m}^{2}$ of the total area of built-up area of $1,670,420.4 \mathrm{~m}^{2}$, which is nearly 22 per cent change (Figure 2, Table 1). Changes

Table 1. Change of the area of different landscape elements in the municipality of Podhájska between 1987 and 2016

\begin{tabular}{|c|c|c|c|c|c|c|}
\hline \multirow{2}{*}{\multicolumn{2}{|c|}{ Indicators ${ }^{*}$}} & \multicolumn{5}{|c|}{ Change of the area of landscape elements in \%, 2016} \\
\hline & & $\mathrm{F}$ & A & $\mathrm{U}$ & Ts & $\mathrm{Tr}$ \\
\hline $\begin{array}{l}\text { Change of the area of land- } \\
\text { scape elements in \%, } 1987\end{array}$ & $\begin{array}{l}\text { F } \\
\text { A } \\
\text { U } \\
\text { Ts } \\
\text { Tr }\end{array}$ & $\begin{array}{l}0.00 \\
1.85 \\
0.00 \\
0.49 \\
0.83\end{array}$ & $\begin{array}{l}0.84 \\
3.50 \\
0.73 \\
0.00 \\
0.00\end{array}$ & $\begin{array}{r}2.03 \\
32.25 \\
37.04 \\
1.05 \\
0.40\end{array}$ & $\begin{array}{r}0.00 \\
0.00 \\
0.00 \\
11.52 \\
0.00\end{array}$ & $\begin{array}{l}0.00 \\
3.34 \\
3.93 \\
0.18 \\
0.03\end{array}$ \\
\hline
\end{tabular}

*Elements of: $\mathrm{F}$ = forest vegetation; $\mathrm{A}=$ agricultural land; $\mathrm{U}=$ urban and recreational areas; $\mathrm{Ts}=$ technical structures; $\mathrm{Tr}=$ transportation 


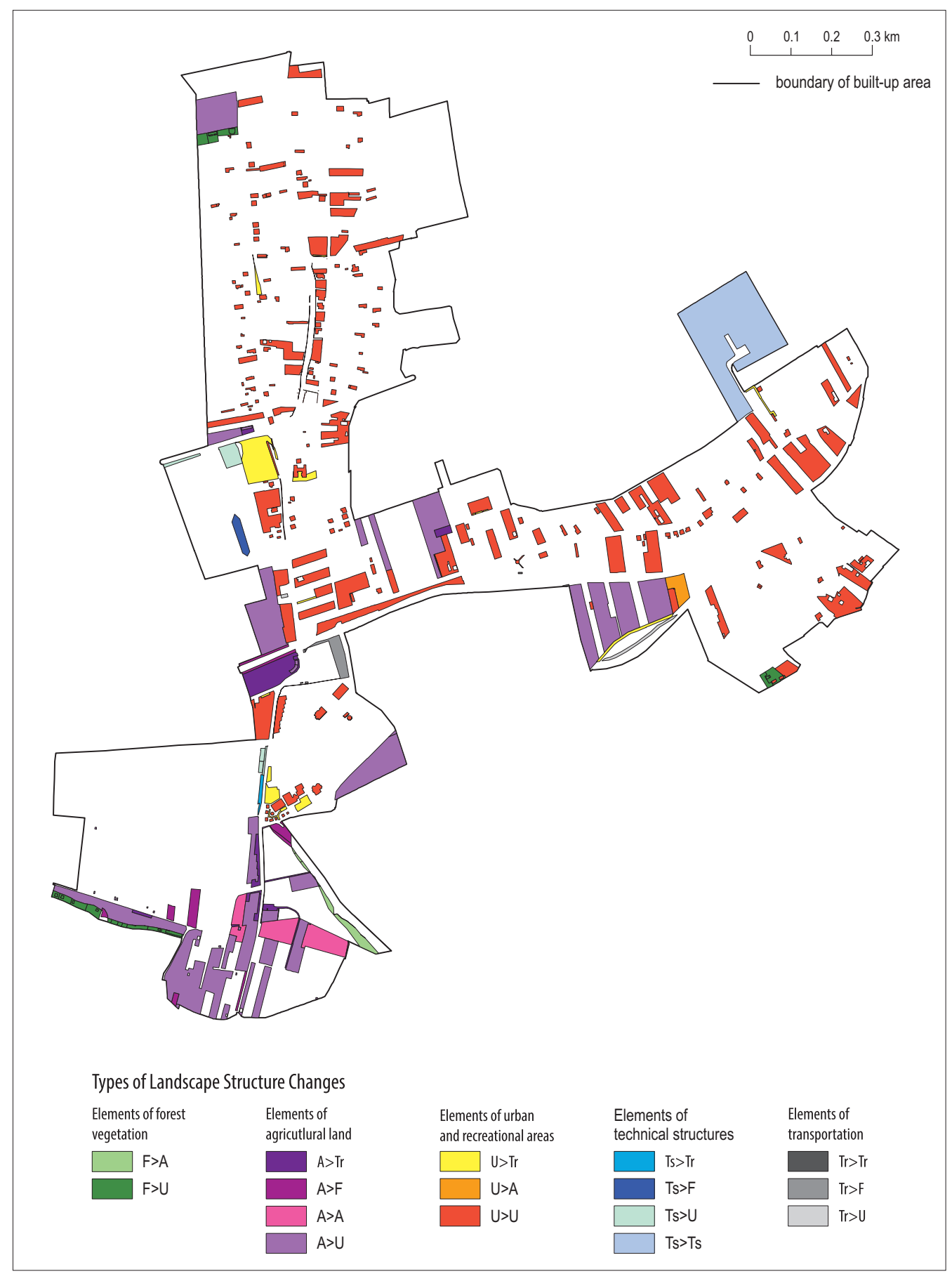

Fig. 2. Localisation of landscape structure changes in built-up area of municipality of Podhájska. - F, A, U, Ts and $\operatorname{Tr}=$ for explanation see Table 1. Source: Žoncová, M. by ArcGIS 10.1 
also occurred in the percentage representation of individual groups of landscape elements (Figure 3). The most visible is the decline in the area of the group of agricultural land elements and the increase in the area of the group of settlements and recreational areas.

In terms of the number of changed landscape elements (Table 2), the number of landscape elements has increased from 1987 to 2016. During this period, 14 landscape elements were transformed into 27 landscape elements. Based on this result, we can claim that the country has diversified considerably and that the observed built-up area becomes more multifunctional

\section{Transformation of gardens}

Approximately one fifth of changes in the observed built-up area consisted in the transformation of the house gardens. In creating a map of the current landscape structure, we have included a new landscape element "recreational garden" in the list of landscape elements. We considered it important to define this landscape element, because these areas form a considerable area of the built-up area of municipality (recreational gardens [7.6\%] and production gardens [35.9\%] in 2016) and therefore it is necessary to pay increased attention to this type of land cover.
The original (former) functional use of houses gardens for growing their own crops, fruit and vegetable gradually disappears and the gardens are transformed into recreational purposes. In such gardens, new features are visible, which was not seen in 1987 (swimming pools, trampolines, large parking spaces, playgrounds, sports grounds, grassy areas, gazebos, fire rings, ponds, ornamental plantings, etc.) (Photo 1).

In contrast to the recreational garden, the production garden is on aerial picture characterized by a miscellaneous structure, space division, more regular mosaic. There is also a higher occurrence of trees in a regular mosaic, which suggests a possible fruit planting. In these gardens, there have also sometimes been farm buildings, which are related to selfsufficiency and work in the garden. However, in many gardens there is also a change of structure, which means that the aerial view on the garden appears to be cultivated only in a certain part, the rest of the land is unused.

This change is also related to the growing importance of tourism in the municipality and, consequently, to the growing number of accommodation facilities. Owners of accommodation want to satisfy all the needs of the tourist and create the most pleasing, visually attractive and clean environment for them. In many cases, it is a redevelopment of existing family houses to accommodation facilities. Individual hous-

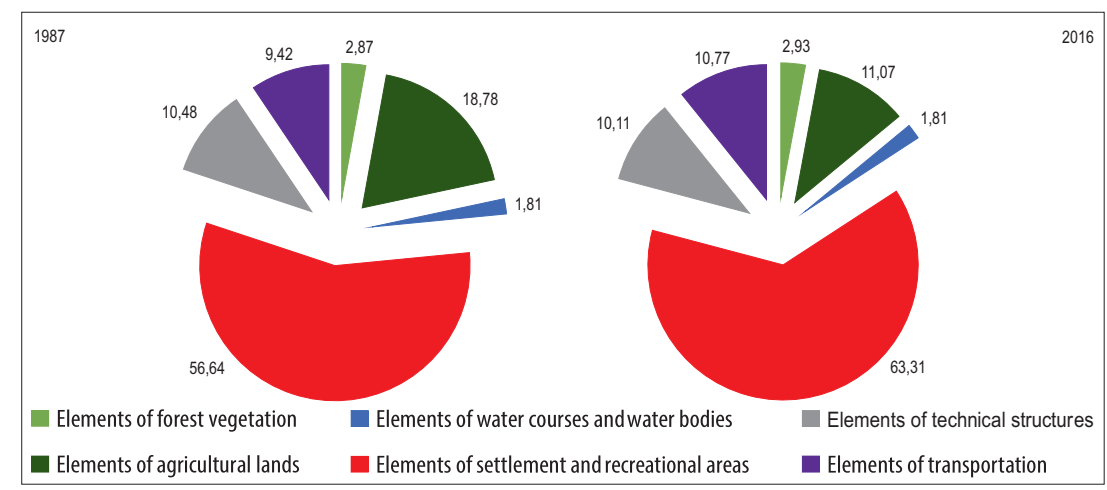

Fig. 3. Landscape structure of built-up area in municipality of Podhájska in 1987 and 2016 in per cent. Source: Authors' own research 


\begin{tabular}{|c|c|c|c|c|}
\hline & 罗 & 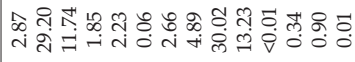 & & 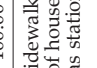 \\
\hline & $\stackrel{\leftrightarrow}{\circ}$ & $\begin{array}{llllllllllllll}1 & 1 & 1 & 1 & 1 & 1 & 1 & 1 & 1 & 1 & 1 & 0 & 0 & 0\end{array} \mid$ & $\Xi_{0}^{\circ}$ & \\
\hline & $\vec{D}$ & 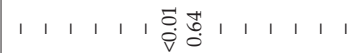 & $\stackrel{\leftrightarrow}{\circ}$ & \\
\hline & $\tilde{\rho}$ & 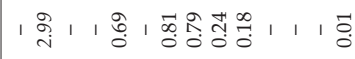 & 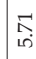 & \\
\hline & 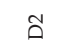 & 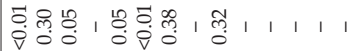 & $\stackrel{9}{7}$ & \\
\hline & $\vec{n}$ & 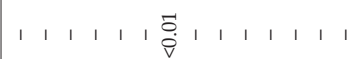 & $\begin{array}{l}\overrightarrow{0} \\
\dot{0} \\
\dot{0}\end{array}$ & \\
\hline & $F$ & 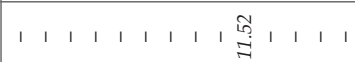 & ?ֶ: & \\
\hline & $\frac{\infty}{\omega}$ & 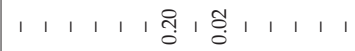 & สู่ & \\
\hline & ले & 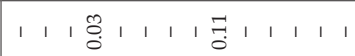 & $\frac{7}{3}$ & \\
\hline & के & 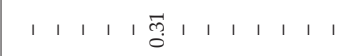 & $\overrightarrow{3}$ & \\
\hline & $\frac{n}{\omega}$ & 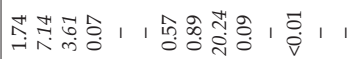 & $\begin{array}{ll}1 \\
c \\
c \\
m \\
m\end{array}$ & \\
\hline & $\ddot{\omega}$ & 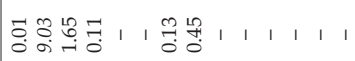 & 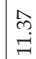 & \\
\hline & $\ddot{\omega}$ & 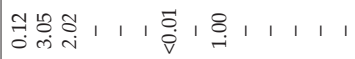 & के & \\
\hline th & $\stackrel{\sim}{\infty}$ & 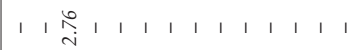 & $\stackrel{\text { i̊ }}{\mathrm{i}}$ & \\
\hline & $\vec{\omega}$ & | 疍 | | I & 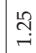 & \\
\hline 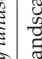 & के & 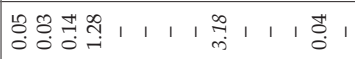 & $\frac{4}{4}$ & \\
\hline & के & 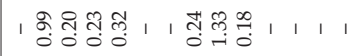 & 鿖 & \\
\hline & $\infty$ & 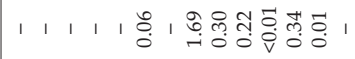 & is & \\
\hline & के & 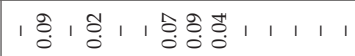 & $\vec{m}$ & \\
\hline & œ & 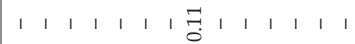 & F & \\
\hline & 点 & 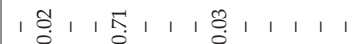 & 点 & \\
\hline & ஆ & 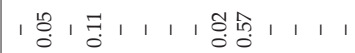 & 占 & \\
\hline & n & 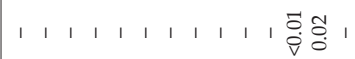 & ठ̊ & \\
\hline & ๙ & 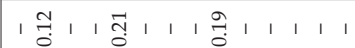 & in & \\
\hline & $\bar{\omega}$ & 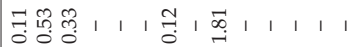 & ì & \\
\hline & $\cong$ & 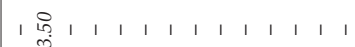 & in & \\
\hline & $\bar{\Xi}$ & 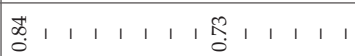 & în & \\
\hline & $\exists$ & 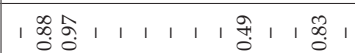 & $\stackrel{\mathrm{c}}{\mathrm{c}}$ & \\
\hline & : & 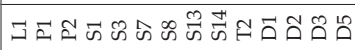 & $\xi$ & \\
\hline & & $\angle 86 \mathrm{~L}$ U! & & \\
\hline
\end{tabular}

ing areas were transformed into accommodation facilities, namely private accommodation $(1.3 \%)$ or hotels, guesthouses $(0.2 \%)$.

The accommodation capacities were also created by the addition of new buildings in the rear parts of the gardens. This method of transforming house gardens into accommodation (hotels, guesthouses, private accommodation, apartment houses) represented almost 5 per cent of the total area of the changed landscape structure. In this case, part of the garden is often used for the original purpose (growing crops) and the second part of the garden for recreation.

Another significant part of the changes $(16.2 \%)$ was the transformation of arable land into house gardens. Most of them were converted into functional house gardens $(9.0 \%)$ and rest into recreational house gardens $(7.1 \%)$. This phenomenon is related to the building of new houses and also gardens. The new houses were mostly created for the residential function of the domestic population as well as for accommodation for tourists. Agricultural land has reduced its area to the detriment of the increase of parking space.

\section{Development of tourism}

As the private business in Slovakia started only after 1989, there was no accommodation capacity in the municipality before that year. However, according to the data from the website ubytovanienaslovensku.sk and the Business register of Slovak republic, accommodation capacities increased significantly after year 2000 .

In the former vineyards, a new urban area is created, which fulfils the recreationalresidential function. There are new large accommodation facilities such as guesthouse Quatro IV, guesthouse Andrejka, guesthouse MeryJan (Photo 2). Large-capacity guesthouses were also built in other parts of the municipality, but not so many (Photo 3 ).

Private accommodation prevails in the local area of Svätuša. Local residents provide their houses, parts of their houses, separate outbuildings, or separate cottages in their 

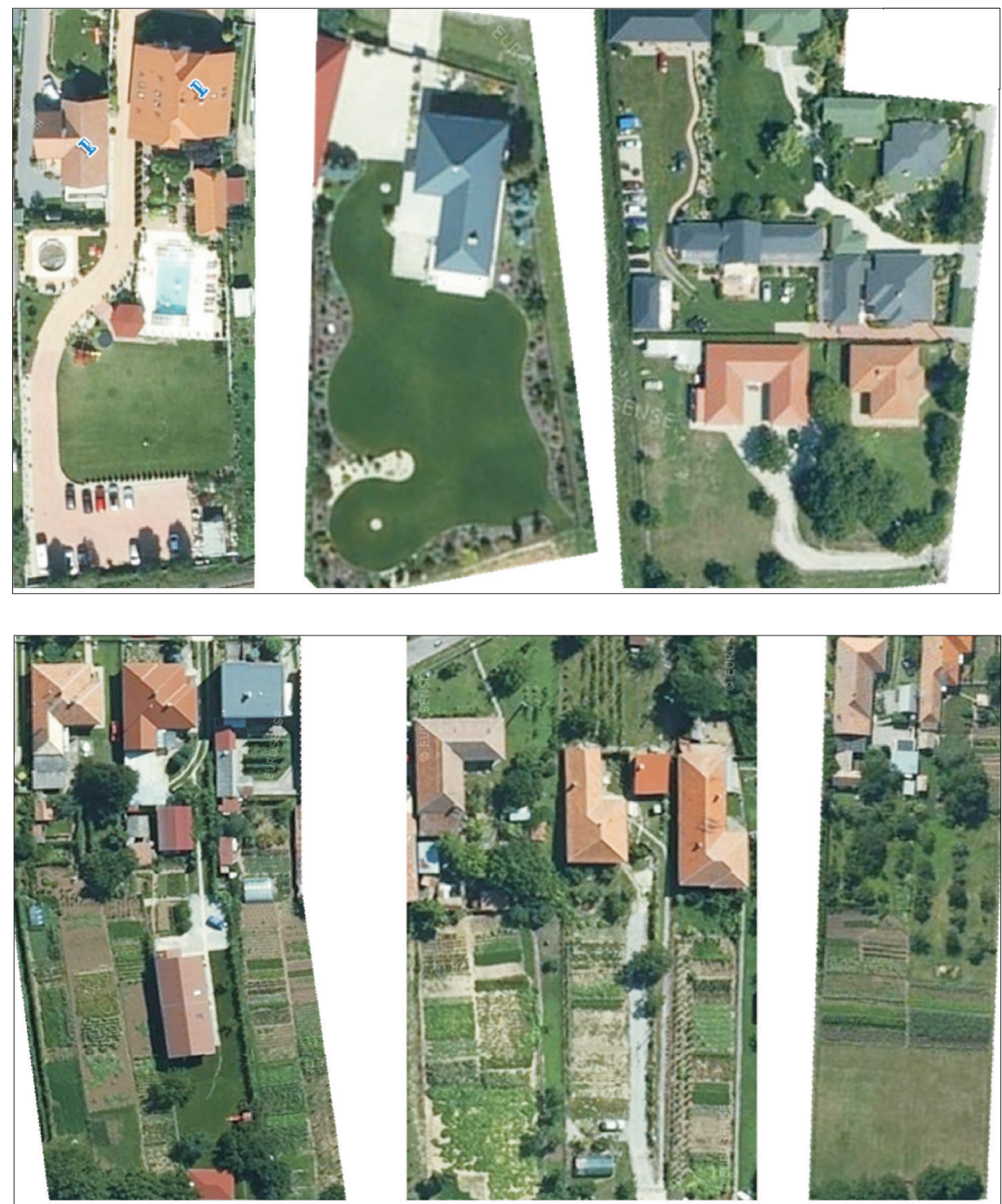

Photo 1. Example of recreational garden (A) and production garden (B) on aerial photo. Source: mapy.cz, 2017

gardens. Most of private accommodation facilities are located in the north of the built-up area of municipality. Around the private facilities, the functional gardens are transformed into recreational gardens. With this way were created several new recreational gardens, representing 3.6 per cent of the total changes.
Part of the agricultural land was transformed into a camping site $(2.8 \%$ of the changes), which was built south of the thermal swimming pool to increase the accommodation capacities in the municipality.

The changes took place also in the area of the thermal swimming pool. The area did not 

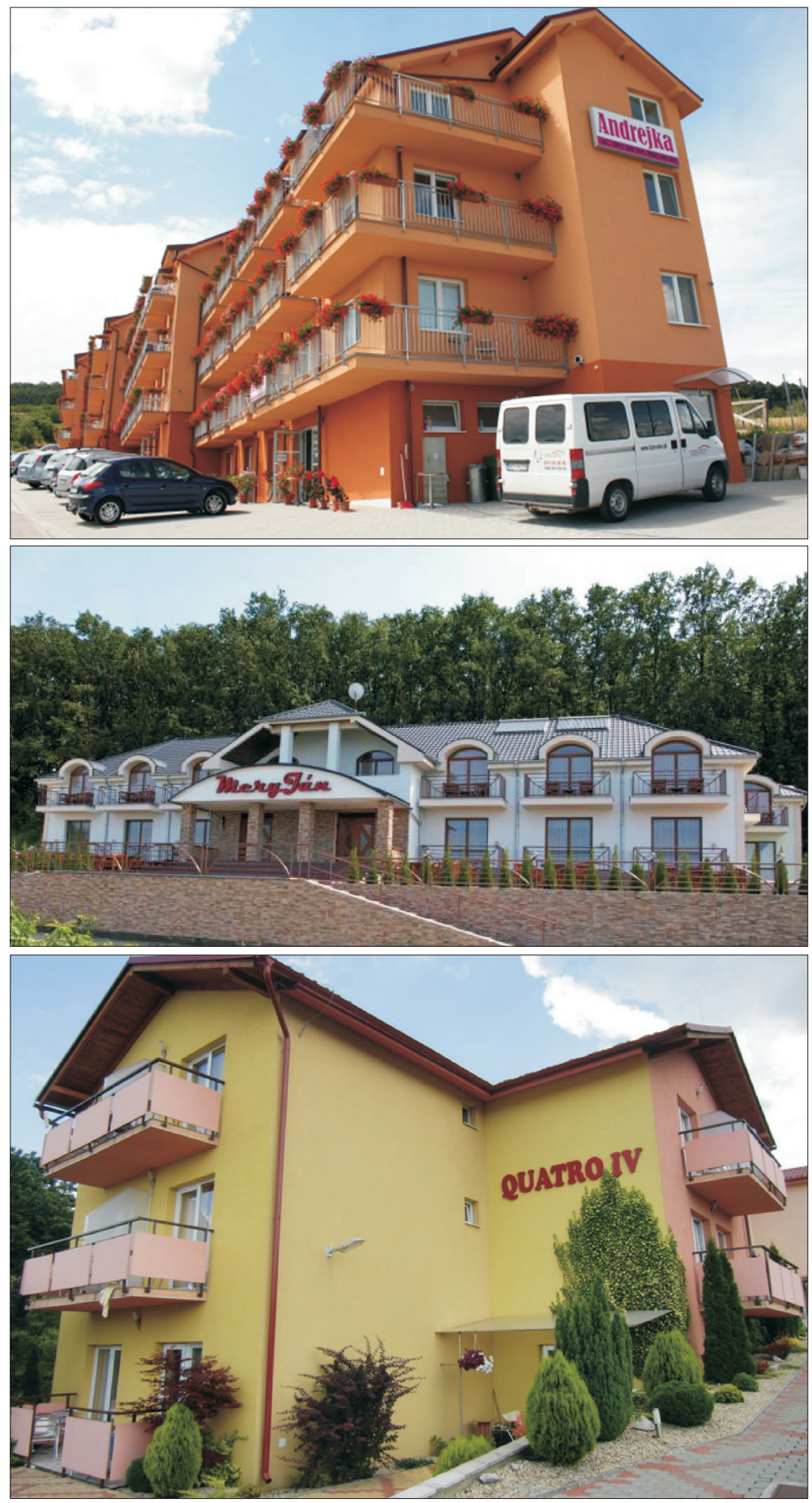

Photo 2. Accommodation facilities in the vineyards area. Source: ubytovanienaslovensku.sk 

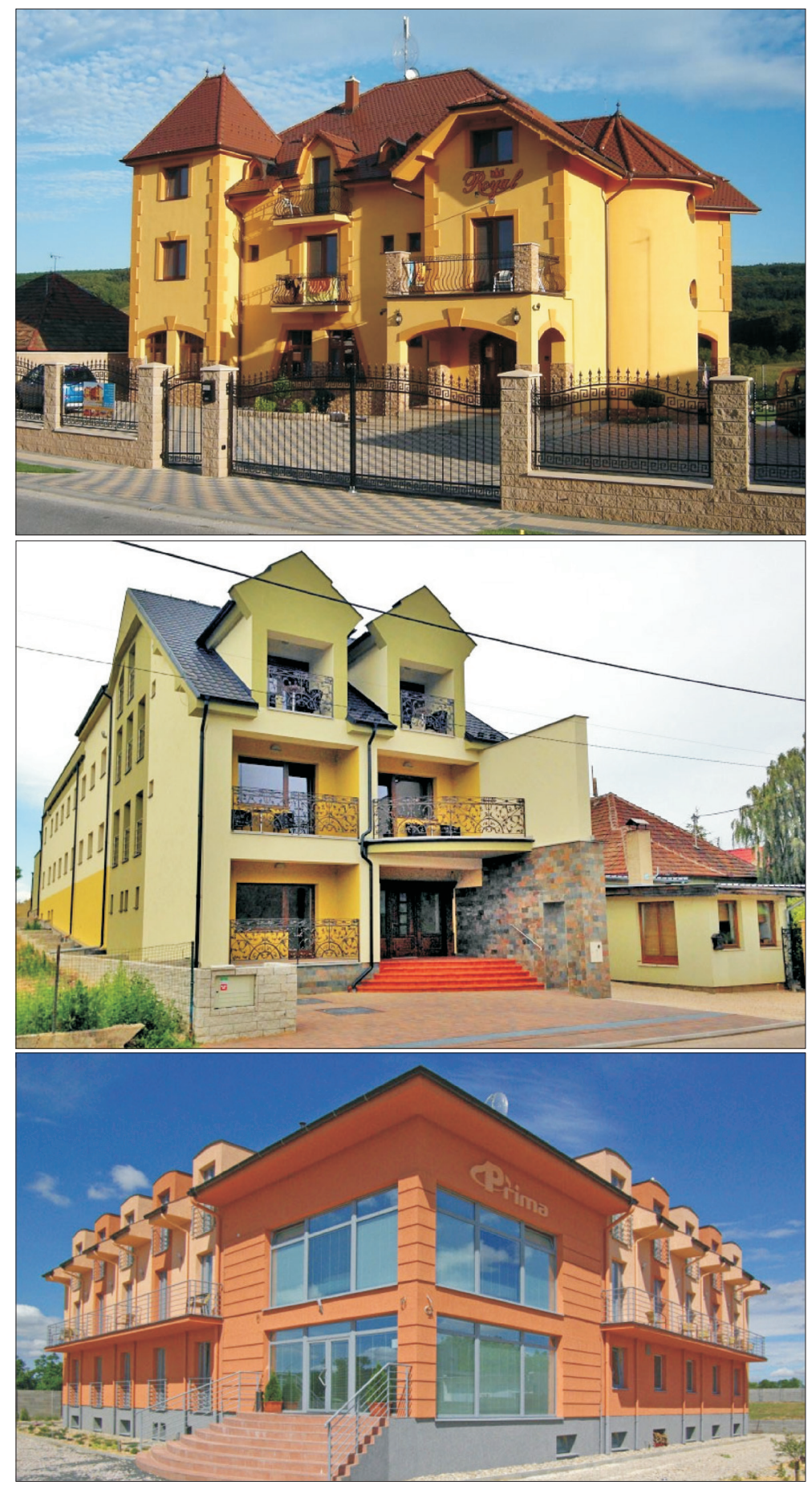

Photo 3. Large-capacity guesthouses beyond the vineyards area. Source: ubytovanienaslovensku.sk 
grow, but it was thickened. In the area of the swimming pool there are new accommodation facilities connected directly to the swimming pool area, new parking areas, new restaurants, sports fields, swimming pools. In 2007 the hotel Borinka was renovated in the area of the swimming pool and the capacity of the hotel was increased. A new Aquamarin wellness center was also completed in 2012.

\section{Multifunctionality of Podhájska}

A spatially large change, but only in one location, was the change in the use of the former agricultural complex in the local part of Belek, where this facility is exploited by Kraintek company since 1990. There was a transformation from the area of the agricultural cooperative to the business area. New buildings have been built in the area and decorative surrounding greenery has been planted. The whole area was so completely revitalized. The transformation of the former agricultural area also took place in the western part of the municipality, where part of the area is currently used as a shop of building material. The rest of the built-up area still functions as an agricultural cooperative and part of the area comes into brownfield.

New landscape elements are also coming to the countryside, not very typical for this environment. In Podhájska is a cinema with an outdoor projection. In 2016, the cinema started its year-round operation in the interior, where is a café, too. In the summer, various cultural events are organized.

The new landscape element in the village is also the P-Petrol gas station on the main road, which originated on an area that had not previously been used.

However, it is important to note that there are not only changes in the area but also functional changes in the municipality of Podhájska. For example, this situation is reflected in the use of the building of the General Office, but also in the use of residential buildings for small and medium-sized enterprises. In the past there was only a mu- nicipal office, currently a municipal office, a library, an information centre as well as a cultural and social centre are housed in the building. A similar situation also occurs in the building on Senčianska Street, where there are groceries, a beer house and the accommodation was completed on the floor.

\section{Discussion}

The monitoring of changes in the landscape structure of the countryside in Slovakia, influenced by natural or anthropogenic factors is also the main object of the research in scientific studies by Malenová, P. (2007), Šolcová, L. (2012) and VoJTEková, J. (2013). They also use aerial photos for detecting changes in landscape. BoltižIAR, M. (2008) claims that the highest advantage of using aerial images is the presentation of the Earth's surface and providing a number of quantitative but especially qualitative information about the individual objects of the landscape whose dynamics can be monitored at different time horizons.

In the Corine Land Cover methodology, a more detailed legend was used to map the landscape cover at a scale of 1:50,000, used by many authors in their works (SviceK, M. 2000; Cebecauerová, M. 2004). We agree with the opinion of KорескÁ, M. (2006), which states that the Corine Land Cover legend does not allow to interpret changes that are important especially in terms of local ecosystem biodiversity (for example, to quantitative reduction of forest vegetation or loss of gardens to the detriment of dissemination of built-up area, evaluate the revitalization of municipalities, etc.), which we also consider to be its main disadvantage.

Based on the map comparison, we found that the changes occurred on an area of $367,145.7 \mathrm{~m}^{2}$ of the total area of the built-up area with area of 1,670,420.4 $\mathrm{m}^{2}$, which represents 22 per cent change. The most visible is the decline in the area of the group of agricultural elements and the increase in the area of the group of settlements and recreational areas. 
When we researched the changes in the landscape structure of the municipality of Podhájska, we have spatially and on a percentage basis analysed the landscape structure in 1987 and 2016. In creating the maps in 2016, we set out a new landscape element - recreational garden. Currently, more than 7.5 per cent of the area is covered by recreational gardens in Podhájska. Changes in the use of gardens are also analysed in research of SupukA, J. et al. (2013), who have observed gardens in the municipality of Tvrdošovce, where up to 25 per cent of gardens are recreational gardens.

When we analysed types of accommodation facilities, there was problem to categorize them according to their quality classification. In this categorization, we found out inaccuracies when accommodation facilities use a different nomenclature of facility in their name, but they do not actually meet the conditions (e.g. they are referred as a guest house and do not meet the conditions). BučEKová, I. (2007) points out this problem, when she examined the network of accommodation facilities in Bratislava. We also consider alarming that accommodation facilities are glutted and concentrated in one municipality.

This enormous increase of commercial and private accommodation facilities also occurs in spa town Mórahalom in Southeast Hungary, where in 2000 only 3 families offered accommodation and in 2009 nearly 80 did. The changes caused only smaller conflicts according to the questionnaire because of tourists parking everywhere. Tourism in general is a fragile business, which depends on many internal and external factor, therefore, a regional economy based only on tourism will never be sustainable (MARTYIN, Z. 2015). Accommodation facilities should also concentrate to surrounding municipalities and focus attention on traffic services. According to Kulusjärvi, O. (2016), a move from "a resort-oriented tourism" towards "a region-based tourism" should be made to achieve long-term business success and sustainable regional development.

\section{Conclusion}

Changing the socio-economic and political conditions after 1989 has resulted in rapid changes in the economy, the way of life of the population, which was reflected mainly in the change of the landscape structure. Based on the research of changes in the landscape structure in Podhájska municipality, we can assess the impacts of the transitory economy on the landscape and identify their positive and negative aspects.

Based on the results of the research, we can identify five basic trends in the development of the observed area, i.e. to define the basic processes that are characteristic for the current countryside: new building, expansion of builtup area of municipality, thickening of the builtup area, change of the function of the areas, revitalization. Countryside is thus becoming a multifunctional space that does not provide only an agricultural function. For this reason, the relationship of the population to the land is often lost, what can be caused also by the fact, that inhabitants are originally from a city and have urban style of life. An emphasis should therefore be placed, on the one hand, on deepening the relationship between man and the countryside, and, on the other hand, on keeping the "genius loci" through the protection of the natural and cultural heritage.

We consider it important to study the changes in the gardens (around the houses), because they form a large part of the builtup area of municipality. The use of gardens is closely related to the intensity of the relationship of the population to the land, which could lead to increased awareness of the growing of own crops on their own parcels. In this way, the relationship of the population to the soil could be revitalized. Attention should also be paid to the disappearance of vineyards around the swimming pool and their transformation into area with accommodation facilities. The vineyards form an integral part of the landscape and increase its heterogeneity, create the landscape image for a long time in the municipality of Podhájska. The direction of the municipality develop- 
ment should also be focused on the support of viticulture or the development of tourism associated with wine tourism.

This work can serve as an example for exploring the changes of rural municipalities and can be used as a basis for further research, for example, for comparing rural changes in other regions or countries, or creation scenarios of future development. These findings can also serve as a base material for further spatial planning of the surrounding municipalities of the Termál micro-region. Then, tourism development would better contribute to socioeconomic development and well-being in local communities. In the next research, it would be interesting to compare the diversification of the rural landscape of a similar micro-region or with other regions or countries of Central Europe (e.g. with regions from the Czech Republic, Hungary or Poland).

\section{REFERENCES}

BAzí́, J. and MuchovÁ, Z. 2016. Land consolidation in Slovakia, where it hangs? In Research for rural development. Eds.: Treija, S. and Skujeniece, S., Jelgava, Latvia University of Agriculture, 201-207.

Benini, L., Bandini, V., Marazza, D. and Contin, A. 2010. Assessment of land use changes through an indicator-based approach: A case study from the Lamone river basin in Northern Italy. Ecological Indicators 10. (1): 4-14.

BezÁK, P. and Mitchley, J. 2014. Drivers of change in mountain farming in Slovakia: From socialist collectivisation to the Common Agricultural Policy. Regional Environmental Change 14. (4): 1343-1356. DOI: 10.1007/s10113-013-0580-x

Bohátová, Z., Schwarcz, P., Schwarczová, L., Bandlerová, A., TĹčik, V. and Mura, L. 2015. Multifunctionality and regional economy management in Kopaniciarsky region of the Slovak republic. Polish Journal of Management Studies 12. (2): 26-36.

BoLTIŽIAR, M. 2008. Využitie výsledkov dial'kového prieskumu Zeme a historických máp pri hodnotení zmien využitia kultúrnej krajiny (Use of results of remote sensing and historical maps for assessing changes of cultural landscape use). In Inovačné učebné texty z geografie. Eds.: Cimra, J. and Neмčí́коvá, M., Nitra, FPV Univerzita Konštantína Filozofa, 195-228.
BuČEKоvÁ, I. 2007. The development of the spatial structure of the hotel network in the territory of Bratislava. Geografický časopis 59. (1): 65-81.

Burian, J., PAszto, V. TučEK, P. et al. 2013. Geoinformatika pri analýzach rurálneho a urbánneho prostoru (Geoinformatics and analyses of rural and urban area). Olomouc, Univerzita Palackého.

Cebecauerová, M. 2004. Analýza a hodnotenie zmien štruktúry krajiny (na príklade časti Borskej nižiny a Malých Karpát) (Analysis and assessment of changes of landscape structure [case study of selected part lowland Borská plain and the mountains Little Carpathians]). Bratislava, Geografický ústav SAV.

Coughlan, M.R. 2014. Farmers, flames, and forests: Historical ecology of pastoral fire use and landscape change in the French Western Pyrenees, 1830-2011. Forest Ecology and Management 312. 55-66.

Feranec, J. 2012. Meniace sa Slovensko očami satelitov (Changing Slovakia by the view of satellites). Bratislava, VEDA.

Feranec, J. and OŤahed, J. 2001. Krajinná pokrývka Slovenska (Land cover of Slovakia). Bratislava, VEDA.

Feranec, J., OŤaheL, J. and Pravda, J. 1996. Krajinná pokrývka Slovenska identifikovaná metódou Corine Land Cover (Land cover of Slovakia identified by Corine Land Cover). Geographia Slovaca 11. Bratislava, Geografický ústav SAV.

HaluzA, I. 2017. Slovak TOP 80 most profitable companies and their paths to success. Accessed: https://www. etrend.sk/trend-archiv/rok-2017/cislo-32/slovenskesuperbiznisy-80-najziskovejsich-firiem-a-ich-cesty-kuspechu-2.html

Holmes, J. 2006. Impulses towards a multifunctional transition in rural Australia: Gaps in the research agenda. Journal of Rural Studies 22. 142-160.

Holmes, J. 2012. Cape York Peninsula, Australia: A frontier region undergoing a multifunctional transition with indigenous engagement. Journal of Rural Studies 28. 252-265.

HrušKa, V. 2013. Diferenciace venkovského prostoru na príkladu Moravskoslezského kraje (The differentiation of rural space in the Moravskoslezský Region). Brno, Masarykova univerzita.

Chirici, G., Corona, P. and Köhl, M.. 2006. Earth Observation Techniques and Geographic Information Systems as Tools for assesing land use/cover changes in a landscape context. In The Conservation of Cultural Landscapes. Ed.: Agnoletti, M., Oxford, CABI, 57-70.

IzAKovičovÁ, Z. 2012. Environmental Quality of the Slovak Rural Settlements. Životné prostredie 46. (4): 176-179.

Johnston, R.J. et al. 1986. The dictionary of human geography. London, Basil Blackwell.

Kanianska, R., Kizeková, M., Nováček, J. and Zeman, M. 2014. Land-use and land-cover changes in rural areas during different political systems: A case study of Slovakia from 1782 to 2006. Land Use Policy 36. 554-566. DOI: 10.1016/j.landusepol.2013.09.018 
Klaučo, M., Gregorová, B., Koleda, P., Stankov, U., Marković, V. and Lemenkova, P. 2017. Land planning as a support for sustainable development based on tourism: A case study of Slovak Rural Region. Environmental Engineering and Management Journal 16. (2): 449-458.

KорескÁ, M. 2006. Identifikcia a hodnotenie zmien krajiny vo vel'kej mierke (na príklade okolia Trnavy) (Identification and assessment landscape changes at the local scale [using the example of the Trnava surrounding]). Geografický časopis 58. (2): 125-148.

Kulcsár, N. 2015. Consumer value dimensions of rural tourism in Hungary. Hungarian Geographical Bulletin 64. (2): 127-141.

Kulusjärvi, O. 2016. Resort-oriented tourism development and local tourism networks - a case study from Northern Finland. Fennia 194. (1): 3-17.

Löw, J. and Míchal, I. 2003. Krajinný ráz (Landscape scene). Kostelec nad Černými lesy, Lesnická práce (Forestry publication).

Mackenzie, J. 2009. Land-Use/Land Cover Transitions in Delaware, 2002-2007. Newark, University of Delaware.

Malenová, P. 2007. Sledovaní vývoje využití území s pomocí GIS (Observing the development of land use using GIS). In Venkovská krajina. Eds.: Dreslerová, J. and Grohmanová, L., Hostětín, Veronica \& IALECZ, 90-94.

Máliková, L. and KLobučNík, M. 2017. Differences in the rural structure of Slovakia in the context of socio-spatial polarisation. Quaestiones Geographicae 36. (2): 125-140. DOI: 10.1515/quageo-2017-0020

Martyin, Z. 2015. A dynamically developing Hungarian spa town: Mórahalom. European Journal of Geography 6. (1): 37-50.

Némethové, J. 2010. Vybrané faktory multifunkčného pol'nohospodárstva v Nitrianskom kraji (Multifunctional agriculture in the Nitra Region). Geographia cassoviensis 4. (2): 131-136.

Nováková, G. and ŠEbo, D. 2016. Recent changes of the visual quality of rural landscape: Case study of Slovak-Austrian borderland. Geographia Polonica 89. (4): 505-520. DOI: 10.7163/GPol.0071

OŤahel, J. and Feranec, J. 1997. Rural landscape assessment in environmental planning: case study - part of the Záhorie Lowland. In Rural Geography and Environment. Eds.: Munzar, J. and VAISHAR, A., Brno, GEOKONFIN, 89-96.

Pazúr, R., Feranec, J., Štych, P., Kopecká, M. and Holman, L. 2017. Changes of urbanised landscape identified and assessed by the Urban Atlas data: Case study of Prague and Bratislava. Land Use Policy 61. (2): 135-146.

Pělucha, M., BednaŘíková, D. and Viktorová, D. 2009. Možnosti nastavení efektivní politiky rozvoje venkova EU (Options for setting up an effective EU rural development policy). Acta Oeconomica Pragensia 5. 53-69. DOI: 10.18267/j.aop.283
Roland, G. 2000. Transition and Economics: Politics, Markets, and Firms. Cambridge, MIT Press.

RuŽıčKA, M. 2000. The principles and criteria of landscape-ecological method LANDEP. Ekológia 19. (2): 18-22.

SpIšIAK, P. 2005. Agrorurálne štruktúry Slovenska po roku 1989 (Agrorural structures of Slovakia after 1989). Bratislava, Geo-Grafika.

STĚPÁNKovÁ, R. and BiHuŇovÁ, M. 2012. Hidden potential of Osadné village. Public recreation and landscape protection - hand in hand. Conference proceeding. Brno, Mendel University, 159-165.

Supuka, J., Feriancová, L'. and Tóth, A. 2013. Urban Agriculture - Traditions and a new Ways of Development. Životné prostredie 47. (4): 237- 241.

Sviceк, M. 2000. Detekcia zmien krajinnej pokrývky analógovou interpretáciou cierno-bielych leteckých snimok (Detection of land cover changes by analog interpretation of panchromatic aerial images). Bratislava, Výskumný ústav pôdoznalectva a ochrany pôdy.

ŠimpaCH, A. and Pechrová, M. 2016. Development of Population in Predominantly Rural Regions of the Czech Republic and Slovakia. In Agrarian Perspectives XXV. Ed.: Smutka, L., Prague, Czech University of Life Sciences, Faculty of Economy \& Management, 371-379.

Šolcová, L. 2012. Vývoj krajiny s disperzným typom osídlenia v Novobanskej štálovej oblasti (Landscape development of dispersed settlement in the Novobanská štálová area). Nitra, FNS Univerzita Konštantína Filozofa.

ŠPulerová, J., BezÁK, P., Dobrovodská, M., Liesovskỳ, J. and ŠTEFUNKOVÁ, D. 2017. Traditional agricultural landscapes in Slovakia: why should we preserve them? Landscape Research 42. (8): 891-903. DOI: 10.1080/01426397.2017.1385749

Tóth, A., Štěpánková, R. and Feriancová, L. 2016. Landscape Architecture and Green Infrastructure in the Slovak Countryside. Prague, Czech University of Life Sciences.

TREND, 2006. Rankings of the largest companies in Slovakia. https://www.etrend.sk/rebricky-firiem. html

Unspecified, 1988. The future of rural society. Commission communication transmitted to the Council and to the European Parliament. Bulletin of the European Communities, Supplement 4/88.

Vojteková, J. 2013. Trendy vývoja banskej krajiny na hornom Ponitrí (Trends in development of mining landscape in the upper Nitra region). Nitra, FNS Univerzita Konštantína Filozofa.

Woods, M. 2011. Rural geography: Processes, Responses and Experiences in Rural Restructuring. London, SAGE.

Žoncová, M. 2017. Diversification of the Rural Landscape of Microregion Termal in Terms of Transitive Economy. Nitra, FNS Univerzita Konštantína Filozofa. 